\title{
Isolation of Cytochrome P-450 cam from Alkaliphilic bacteriaKocuria sp. DL
}

\author{
Munif A. Othman, Ahmed T. Ahmed and Kachru. R. Gawai* \\ Department of Chemistry, University of Pune, Pune-411 007, India
}

\begin{abstract}
Cytochrome $P-450$ is a terminal oxidase, involved in biotransformation of endogenous and exogenous substances. Cytochrome P-450 cam is isozyme present in various bacteria. CYP-450 cam was purified from alkaliphilic bacteria, Kocuria sp. DL, isolated from pristine alkaline Crater Lake, Lonar, (Maharashtra State), India. Identification of this bacterial strain was carried out by analysis of 16S rRNA gene sequence [Kocuria species DL strain]. The content of CYP-450 cam was found to be $2.68 \mathrm{n} \mathrm{mol} / \mathrm{mg}$ of protein in $50 \mathrm{~h}$ grown culture under aerobic condition. Purification of CYP-450 cam was carried out by applying analytical procedures at $4{ }^{\circ} \mathrm{C}$. The $K_{m}$ values for both aminopyrine and acetanilide were 0.4 and $0.25 \mathrm{mM}$, respectively. The maximal velocity $V_{\max }$ was 12.98 and $13.2 \mathrm{mM} / \mathrm{mg}$ of protein per min for aminopyrine and acetanilide, respectively. The optimal $\mathrm{pH}$ and temperatures were found to be 7.4 and $40{ }^{\circ} \mathrm{C}$, respectively. The purification fold was found to be 6. The molecular mass was found to be $48 \mathrm{kDa}$. Thermal stability of purified $\mathrm{CYP}-450_{\text {cam }}$ is up to $40^{\circ} \mathrm{C}$. This enzyme has shown the characteristic type-I and type-II substrate binding spectra.
\end{abstract}

Key Words:Alkaliphilic, Kocuria sp. DL, Cytochrome P-450 cam, Aminopyrine, Acetanilide, Lonarlake.

\section{Introduction}

The cytochrome P-450 constitutes an extremely large family of hemoprotein, which catalyze the biotransformation of a wide range of endogenous and exogenous compounds. It is widely distributed in all species of mammals and bacteria and fungi. The first experimental evidence of existence of CYP-450 in rabbit liver microsomes was made in 1955 by Axelrod[1] and Brodie et al.[2], who identified an enzyme system in the endoplasmic reticulum of the liver, which was able to oxidize xenobiotic compounds. In 1958, Garfinkel[3] and Klingenberg[4] detected a CO binding pigment in liver microsomes, which had an absorption maximum at 450 $\mathrm{nm}$.

Bacterial CYP-450 is mainly present in soluble fraction of the cell and involved in critical metabolic processes. Structural features and mechanism of action of CYP-450 putida (CYP101)[5] and has been used as a model for many CYP-450, it was the first 3-D structure solved by Xray crystallography. This CYP450 cam is part of a camphor-hydroxylating catalytic cycle consisting of two electron transfer steps from putidaredoxin, a $2 \mathrm{Fe}^{-2} \mathrm{~S}$ cluster-containing protein cofactor. In bacteria, CYP-450, vary qualitatively and quantitatively from one species to another and even in a given species under different growth conditions[6]. Cytochrome-450 eryF (CYP107A1)[7] from the erythromycin-metabolizing bacteria Saccharopolyspora erythraea [8] is responsible for the biosynthesis of the antibiotic erythromycin by C-6hydroxylation of the macrolide 6-deoxyerythronolide Bhydroxylase[9]. CYP-450 BM3 from the soil bacterium Bacillus megaterium catalyzes the NADPH-dependent hydroxylation of several long-chain fatty acids at the $\omega-1$ through $\omega-3$ positions. Unlike almost every other known CYP [except CYP505A1, from liver cytochrome $\mathrm{P}_{450}$ foxy (5-methoxy-N, N-diisopropyltryptamine)], it constitutes a natural fusion protein between the CYP domain and an electron donating cofactor. Thus, BM3 is potentially very useful in biotechnological applications[10-11].

The camphor hydroxylase CYP101 from Pseudomonas putida has been engineered to biotransform other substrates, including halogenated aromatic compounds[12-13]. Camphor is the most universally used substrate to induce the bacterial CYP-450 cam syntheses, which hydroxylate camphor to 5-hydroxy-camphor and form $\mathrm{OH}$ and $\mathrm{H}_{2} \mathrm{O}$ molecules. Lewis et al, has mentioned that alkaliphiles have much higher cytochrome contents than conventional bacteria and then their own non-alkaliphilic mutants[14]. Davidson et al, had attempted to purify two soluble cytochromes from the alkalophile Bacillus firmus[15]. Yumoto et al, has purified and characterized two membrane-bound c-type cytochromes from a facultative alkaliphilic Bacillus[16]. A comparative studies of 10 facultative alkaliphilic bacteria was studied by Isao Yumoto 1997, two obligate alkaliphiles having relatively high total cytochrome concentrations are seen to possess considerably higher amounts of cytochrome $b$ and cytochrome $c$, whereas, the amount of cytochrome $a$ was not noticeably higher[17].CYP-450 119 isolated from 
the thermophilic archea Sulfolobus acidocaldarius[18] has been used in a variety of mechanistic studies[19]. Because thermophillic enzymes evolved to function at high temperatures, they tend to function more slowly at room temperature and are therefore excellent mechanistic models.

Alkaliphiles are one of the extremophiles organisms that thrives in an extreme environment in more than one extreme, these organisms has adapted their physiological character towards alkaline $\mathrm{pH}$ and grow optimally or very well at $\mathrm{pH}$ values above 9.0 often between 10 and 12, but do not grow or grow only slowly at neutral $\mathrm{pH}$ values[20]. Various types of alkaliphiles have been isolated and reported. The bacteria belonging to the genera Bacillus,Micrococcus, Pseudomonas, Streptomyces and eukaryotes such as yeasts, filamentous fungi, have been isolated from a variety of environments. A number of proteolytic and hydrolytic enzymes have been isolated from the alkaliphiles that have industrial applications[21]. Additionally, microorganisms have also contributed to clean up the contamination in the environment employing their enzymes. There is enough data about CYP-450 from neutrophiles, much has to be done regarding the CYP-450 from alkaliphilic bacteria. Therefore, in present studies, the attempt has been made to isolate the alkaliphilic bacterial strains from Pristine Crater Lake of Lonar M.S., India and to purify and characterize cytochrome P-450 $0_{\text {cam }}$ from these strains.

\subsection{Chemicals}

\section{Materials and methods}

Sodium dithionate $\left(\mathrm{Na}_{2} \mathrm{~S}_{2} \mathrm{O}_{4}\right)$, aminopyrine $\left(\mathrm{C}_{13} \mathrm{H}_{17} \mathrm{~N}_{3} \mathrm{O}\right)$, and sephadexG-75 (Sigma,USA), DEAEcellulose (DO909-100G) from (Sigma-Aldrich, U.K), DMSO (MERCK), 500bp DNA ladder (Bangalore Genei, India) EDTA, DTT, NADPH Na $\mathrm{NaDTA}_{4}$, DTT, sodium-formate, $\mathrm{H}_{2} \mathrm{SO}_{4}$, acetanilide, ammonium sulphate, $\mathrm{NaOH}, \mathrm{HCl}$, SDS, $\beta$-mercaptoethanol, bromophenol blue, coomassie brilliant Blue R-250, and glycerol were obtained from (SRL, India), aniline, $1 \times \mathrm{TAE}$ buffer, $\mathrm{MgCl}_{2}$, dNTP mix, Taq polymerase enzyme, Protease $\mathrm{K}$, DNAzol, \& triton X-100(Merck, India), camphor 99.9\% (Loba-chem, India), peptone, yeast extract, agar, $\mathrm{NaCl} \&$ bovine serum albumin(HIMEDIA, India), Ethidium Bromide, and TCA from (Sd-Fine Chemicals Mumbai), R-salt was synthesized in our laboratory, All other chemicals were of the highest grade of purity and commercially available.

\subsection{Isolation of microorganism and growth conditions}

The Kocuria sp. $D L$ strain used in this work was isolated from alkaline Crater Lake, Lonar (M.S.) India. Was grown in 1 liter bioreactor in agitating conditions, the nutrient broth medium contained the following (in grams per liter): $5.0 \mathrm{gm}$ yeast extract, 5.0 peptone, $5.0 \mathrm{gm} \mathrm{NaCl}$, trace elements, $\mathrm{KH}_{2} \mathrm{PO}_{4} 170 \mathrm{mg}, \mathrm{Na}_{2} \mathrm{HPO}_{4}$ $980 \mathrm{mg},\left(\mathrm{NH}_{4}\right)_{2} \mathrm{SO}_{4} 100 \mathrm{mg}, \mathrm{MgSO}_{4} 0.87 \mathrm{mg}, \mathrm{MgO}_{2} 0.1 \mathrm{mg}$ and the $\mathrm{pH}$ was adjusted to 10.5 . The culture media in bioreactor was inoculated with $10 \mathrm{ml}$ of microorganism suspension and incubated for $48 \mathrm{hrs}$. After attaining the optical density about 1.0 , a $60 \mathrm{mg} / 100 \mathrm{ml}$ of camphor were added.

\subsection{Identification of the microorganism by $16 \mathrm{~S}$ rRNA method}

The isolated bacteria strain was grown aerobically on nutrient agar. DNA was isolated by using DNAzol method[22]. DNA solubilization, supernatant was precipitated by using chilled absolute ethanol (Omnis, Jebsen\&Jessen, GmbH, Germany), Extracted DNA was subjected to 16s rRNA PCR.Nucleotide data of $16 \mathrm{~s} r$ RNA gene of the isolated alkaliphilic was deposited to NCBI nucleotide database.

\subsection{DNA sequencing, BLAST and Phylogeny}

PCR product was sequenced by Sanger's Dideoxy chain[23] termination method and the phylogenic analysis was constructed by using a Neighbor-Joining (NJ) method[24] in MEGA 4.1 software[25-26].

\subsection{Cytochrome P-450 $0_{\text {cam }}$ Purification}

2.5.1 Crude cell extract preparation:

Cell mass from culture was collected by centrifugation at $10,000 \times \mathrm{g}$ for $30 \mathrm{~min}$ at $4^{\circ} \mathrm{C}$ in a DupontSorvall RC-5B refrigerated centrifuge, washed with physiological saline and two times with $0.1 \mathrm{M}$ $\mathrm{NaH}_{2} \mathrm{PO}_{4}$ buffer, ( $\mathrm{pH}$ 7.4). The pellets were suspended in $50 \mathrm{ml}$ of the same buffer containing $0.1 \mathrm{mM}$ EDTA, $0.1 \mathrm{mM}$ DTT, $1 \mathrm{mM}$ lysozyme and $20 \%$ glycerol (v/v). Cells were disrupted in the cold condition by sonication three times lasting for 30 second with 1 minute interval and 70\% outputs using a Sartorius Lab Sonic. Cells debris was removed by centrifugation at $10,000 \times \mathrm{g}$ for $30 \mathrm{~min}$ at $4^{\circ} \mathrm{C}$ in the refrigerated centrifuge. The supernatant obtained constitutes the crude bacterial extract was used for further studies.

\subsubsection{Estimation of protein:} a standard.

Concentration of protein at each step of purification was checked by Lowry's method[27] using BSA as 


\subsection{Assay of Cytochrome P-450 $0_{\text {cam }}$ content:}

The content of CYP-450 cam was determined spectrophotometrically at room temperature using a UVvisible spectrophotometer, JascoV630, by the method of Omura and Sato (1964)[28]. Total P450 content were determined by the CO bound minus oxidized UV-VIS spectra with $\square_{450-500 \mathrm{~nm}}=91 \mathrm{mM}^{-1} \times 1000$.

\subsection{Puri $\square$ cation of CYP-450}

The Cytochrome $\mathrm{P} 0450_{\text {cam }}$ was purified by a five-steps procedure carried out at $4{ }^{\circ} \mathrm{C}$.

\subsubsection{Ammonium sulfate precipitation}

Solid ammonium sulfate was added to the crude extract over a period of $4 \mathrm{~h}$ in cold condition with constant stirring to get the $30 \%$ saturation. The resulting precipitate was separated by centrifugation, and the supernatant further saturated up to $80 \%$ with solid $\left(\mathrm{NH}_{4}\right)_{2} \mathrm{SO}_{4}$ [29]. The resulting precipitate was collected by centrifugation at $15,000 \mathrm{rpm}$ for $30 \mathrm{~min}$ in a cold centrifuge. The precipitate was dissolved in a minimal volume of $100 \mathrm{mM}$ phosphate buffer, $\mathrm{pH}$ 7.4. The protein solution was dialyzed against the same buffer for $36 \mathrm{hrs}$ with repeated changes.

\subsubsection{Ion-exchange chromatography}

After dialysis, the solution was loaded on pre-equilibrated DEAE-cellulose column $(2 \mathrm{~cm} \times 30 \mathrm{~cm})$ the column was thoroughly washed with equilibrating $0.1 \mathrm{M}$ phosphate buffer $\mathrm{pH} 7.4$ containing, $0.1 \mathrm{mM}$ EDTA, $0.1 \mathrm{mM}$ DTT, and $20 \%$ glycerol $(\mathrm{v} / \mathrm{v})$. The protein was eluted with a linear gradient of $\mathrm{NaCl}(0-500 \mathrm{mM})$ in a $0.1 \mathrm{M}$ phosphate buffer. Fractions of $3 \mathrm{ml}$ were collected, those fractions showed higher content of CYP- $450_{\text {cam }}$ were pooled and reverse dialyzed in sucrose in cold condition to reduce the volume and dialyzed against same buffer for $36 \mathrm{~h}$ to remove the salt content, then was keep for reveres dialysis to concentrate the proteins.

\subsubsection{Calcium phosphate gel Negative Adsorption:}

Was prepared on lab according to the methods of Keilin and Hartree[30].

\subsubsection{Molecular exclusion chromatography}

The reversed dialyzed preparation was then applied to a Sephadex G-75 column $(2 \mathrm{~cm} \times 30 \mathrm{~cm})$ at $4{ }^{\circ} \mathrm{C}$ and equilibrated with $0.1 \mathrm{M}$ phosphate buffer $\mathrm{pH} 7.4$ containing, $0.1 \mathrm{mM}$ EDTA, $0.1 \mathrm{mM}$ DTT, and 20\% glycerol (v/v). The enzyme was eluted with a flow rate of $10 \mathrm{ml} / \mathrm{h}$. Fractions of $3 \mathrm{ml}$ were collected and those showed higher CYP-450 cam content were pooled together.

\subsection{Characterization of purified Cytochrome $P-450_{\text {cam }}$}

\subsubsection{SDS-PAGE gel electrophoresis}

SDS-polyacrylamide gel electrophoresis [SDS-PAGE] was performed with 5\% stacking and $12 \%$ resolving polyacrylamide gel according to the method of Laemmli[31].

\subsubsection{Substrate binding studies:}

Binding of type-I substrate (aminopyrine) and type-II substrate (acetanilide) was carried out according to the procedure of Schenkman et al[32].

\subsubsection{Catalytic activity of purified CYP-450 $0_{\text {cam }}$}

The ability of cytochrome P- $450_{\text {cam }}$ to catalyze the $N$-demethylation of aminopyrine and hydroxylation of Acetanilide was examined by (Schenkman 1967)[32].

\subsubsection{Determination of optimal $\mathrm{pH}$ and temperature of purified CYP-450 $\mathrm{cam}$}

The influence of $\mathrm{pH}$ on the CYP-450 cam activity was studied over a wide range of $\mathrm{pH}$ (from 3.6 to 10.7) using a mixture of different buffers adjusted to the same ionic strength $100 \mathrm{mM}$ (Tris-HCl, sodium phosphate, and sodium acetate). Effect of temperature on activity of CYP-450 cam was studied by conducting the CYP$450_{\text {cam }}$ assay at temperature range from 10 to $90^{\circ} \mathrm{C}$ using JASCO V-630 spectrophotometer with temperature adaptor ETC-717, the activity was determined as described in section 2.7. The obtained data were plotted against the effect of temperature on activity and stability with time.

\subsubsection{Determination of thermal stability}

The enzyme samples were pre-incubated with $100 \mathrm{mM}$ phosphate buffer $(\mathrm{pH}$ 7.4) at different temperatures between 10 and $80{ }^{\circ} \mathrm{C}$ for $30 \mathrm{~min}$ and then brought to room temperature. At every interval temperature time the enzyme activity was measured as indicated in Section 2.7. \& 2.9.3. 


\section{Results}

\subsection{Isolation and identification of bacterial strain Kocuria sp. $D L$.}

The isolated alkaliphic species is a gram positive curved rod with high GC containing bacteria. The alkaliphilic strain Kocuriasp $D L$, was found to have a higher ability to degrade the camphor under aerobic conditions and was grown aerobically at $37^{\circ} \mathrm{C}$ for $50 \mathrm{~h}$. The red pigmented colonies from pure culture were used for bacterial DNA isolation. The 16S rRNA gene was amplified by PCR using the conserved region primers in the 16S ribosomal RNA gene, and its nucleotide sequence was determined by Sanger's method[23]. From BLAST analysis, it was found that the $16 \mathrm{~S}$ rRNA gene sequence of red pigmented alkaline bacteria was 100 per cent identical to sequences of Kocuriarosea strains. Also, pair-wise distance computation derived by maximum composite like Neighbor-Joining (NJ) method[24] in MEGA 4.1 software[25,26] suggests very close relation of Kocuria species $D L$ with Kocuriarosea species within Kocuria genus as supported by phylogenetic analysis of species within Kocuria genus. Accession number received for deposited nucleotide data and is available under the Gen Bank (GenBank ID:HM439779) more details are in supported supplementary data.

\subsection{Purification of CYP-450 ${ }_{\mathrm{cam}}$ from Kocuria sp. $D L$.}

Table-1 summaries the purification of CYP-450 $0_{\text {cam. }}$. A total amount of protein $159 \mathrm{mg}$ was obtained from crude extract of disrupted cells of Kocuriasp. $D L(20 \mathrm{~g}$ wet weight). During the purification process approximately $50 \%$ of other proteins were eliminated during ammonium sulfate precipitation. The concentrated enzyme solution after dialysis was applied on DEAE-cellulose column followed by calcium phosphate gel and then to Sephadex G-75 yielding a purification fold of approximately 6.0 giving $2.68 \mathrm{n} \mathrm{mol} / \mathrm{mg}$ of CYTP-450 (Fig.1.A). Molecular weight of CYP-450 camwas estimated by SDS-PAGE with molecular marker proteins and was found to be $48 \mathrm{kDa}$ (Fig.1.B). The Purification and characterization of the enzymes was studies well with triplicate sets.

\subsection{Spectral Properties:}

The major form of CYP-450 $0_{\text {cam }}$ obtained from camphor induced culture showed CO-reduced absorbance maxima at $452 \mathrm{~nm}$, while the oxidized showed absorbance maxima at $414 \mathrm{~nm}$ and the dithionate reduced showed absorbance at $412 \mathrm{~nm}$. The absorbance spectrum of the purified CYP-450 cam from Kocuriasp. DLis shown in (Fig.2).

\subsection{Substrate binding spectra:}

Purified CYP-450 cam has shown typical type-I and type-II substrate binding spectra with aminopyrine and acetanilide respectively (Fig.3.A and B) spectrum of type-I with a slight shift in peak at $\pm 384 \mathrm{~nm}$ and a trough at $418 \mathrm{~nm}$, with an isosbestic point at $401 \mathrm{~nm}$, as binding of the ligand is increased $\mathrm{K}_{\mathrm{s}}$ values was (26.5). Acetanilide, a type-II substrate (Fig.3.B) exhibited its characteristic peak at $425 \mathrm{~nm}$ and trough at $389 \mathrm{~nm}$ with an isosbestic point at $408 \mathrm{~nm}$, the $\mathrm{K}_{\mathrm{s}}$ value was (103).

\subsection{Catalytic activity:}

The purified CYP-450 $0_{\text {cam }}$ has efficiently catalyzed the $N$-demethylation of aminopyrine and $p$ hydroxylation of acetanilide.

\subsection{Effect of $\mathrm{pH}$ and temperature}

The effect of $\mathrm{pH}$ on the activity of drug metabolizing enzymes was also examined. The maximum activity was at $\mathrm{pH} 7.4$ for both aminopyrine- $N$-demethylase and acetanilide-hydroxylase. (Fig.4.A).Similarly the effect of temperature on the activity of these enzymes was also studied. The maximum activity was observed at $40{ }^{\circ} \mathrm{C}$. The CYP-450 $0_{\text {cam }}$ was stable up to $45^{\circ} \mathrm{C}$ and then the activity was decreased with increase in the temperature. (Fig.4.B).

\subsection{Kinetic studies}

To obtain the $\mathrm{K}_{\mathrm{m}}, \mathrm{V}_{\max }$ and $\mathrm{K}_{\text {cat }}$ values, aminopyrine- $N$-demethylase and acetanilide-hydroxylase activities was measured by varying the concentrations of the substrates aminopyrine and acetanilide. In case of aminopyrine the values of $K_{m}$ and $V_{\max }$, were $0.4 \mathrm{n} \mathrm{mol}$ and $12.98 \mathrm{n} \mathrm{mol}$ and $\mathrm{K}_{\text {cat }} \pm 9.19 \mathrm{~S}^{-1}$. And in case of acetanilide were found to be $0.25 \mathrm{n} \mathrm{mol}, 13.2 \mathrm{n}$ mol\& $\mathrm{K}_{\text {cat }} \pm 8.35 \mathrm{~S}^{-1}$, respectively (Table-2).

\section{Discussion}

The report describes the identification of alkaline bacterial strain Kocuria sp. $D L$ by 16s rRNA gene sequence, which is very closely related to Kocuriaroseastrains. The alkaliphilicbacterium was grown in alkaline nutrient broth and the purification and characterization of the CYP-450 $0_{\text {cam }}$ was studied well with triplicate sets. The purification of CYP- $450_{\text {cam }}$ was difficult because of low content of CYP- $450_{\text {cam }}$ but it was easily soluble 
with sodium cholate. Purified CYP-450 $0_{\text {cam }}$ has shown the efficient catalytic and spectral properties. The purified sample contained $2.68 \mathrm{n} \mathrm{mol} / \mathrm{mg}$ of CYP-450 cam $_{\text {wh }}$ which comparatively with other species are little more[33-34]. The monomeric molecular weight was found to be $48 \mathrm{kDa}$. The re-activation of CYP-420 to CYP-450 was difficult till dialyzed with a phosphate buffer pH 7.4 containing $20 \%$ glycerol for $30 \mathrm{hrs}$. The Purified CYP$450_{\text {cam }}$ has exhibited thermal stability similar to CYP119 from Sulfolobussolfataricus[35] which grows in volcanic springs, and Thermobifidafusca[36]unlike other for example CYP102A1 monooxygenase that require a thermo-stable analog of the reductase domain from Bacillus megaterium[36-37]. CYP450 $0_{\text {cam }}$, heme containing protein from Kocuriasp. $D L$, is expected to be one of the most versatile enzymes in nature and could efficiently catalyze hundreds of different substrates through a variety of difficult biotransformations.

In this study, we observed that the CYP-450 cam from Kocuria $s p$. DL has hydroxylated camphor to 5hydroxy-camphor and form $\mathrm{OH}$ and $\mathrm{H}_{2} \mathrm{O}$ molecules. Stability of CYP-450 $0_{\text {cam }}$ to achieve maximum activity at neutral (around $\mathrm{pH}$ 7.4) and half at alkaline $\mathrm{pH}$ suggest that the cell internal $\mathrm{pH}$ is at slight alkaline condition although the $\mathrm{pH}$ of the growth medium was above $\mathrm{pH} 10.0$, this enzyme can tolerate the temperature up to $60^{\circ} \mathrm{C}$ with $50 \%$ of initial activity and further increase in temperature showed a decrease in activity, hence we concluded that the CYP-450 $0_{\text {cam }}$ is thermo stable. Type-I and type-II spectra properties changes are small, and they resemble those obtained from other sources of CYP-450[32]. The purified CYP- $450_{\text {cam }}$ has efficiently catalyzed the $N$-demethylation of aminopyrine and $p$-hydroxylation of acetanilide. The activities of aminopyrine- $N$-demethylase and acetanilide- $p$-hydroxylase were found to be $56 \mathrm{n} \mathrm{mol} / \mathrm{mg} / \mathrm{min}$ and $83 \mathrm{n}$ $\mathrm{mol} / \mathrm{mg} / \mathrm{min}$ of product, respectively.

CYP-450 $0_{\text {cam }}$ showed a significant activity for aminopyrine and acetanilide. Acetanilide was found to be the best substrate for the enzyme. This is the first report on CYP-450 $0_{\text {cam }}$ from alkaliphilic bacteria; the isolated enzyme could contribute a great development for the drug synthesis under the biotechnology aspect.

\section{Acknowledgements}

Munif A. A. Othman gratefully acknowledges a fellowship from Indo-Yemen exchange program and Department of Chemistry University of Pune for the infrastructure support.

\section{Reference:}

[1]. J. Axelrod,The enzymatic demethylation of ephedrine, J. Pharmacol. Exp. Ther. 114(1955) 430-8

[2]. B. Brodie, J. Axelrod, J. R. Cooper, et al.,Detoxication of drugs and other foreign compounds by liver microsomes,Science. 121, (1955)603-4.

[3]. D. Garfinkel, Studies on pig liver microsomesI. enzymic and pigment composition of different microsomal fractions, Arch. Biochem. Biophys. 77,(1958)493-509.

[4]. M. Klingenberg, Pigments of rat liver microsomes.Arch.Biochem.Biophys.409(1),(2003)2-6.

[5]. O. Pylypenko, I. Schlichting, Structural aspects of ligand binding to and electron transfer in bacterial and fungal P450s, Annu. Rev. Biochem. 73, (2004) 991-1018.

[6]. P.P Guengerich, P.Wang, N.K. Davidson, Estimation of isoenzymes of microsomal cytochrome P450in rats, rabbits and humans, Biochemistry.21, (1982) 1698-706.

[7]. V. Guallar, L. H. Danni, S. B. Victor, et al., Proton-Transfer Dynamics in the Activation of Cytochrome P450eryF, J. Am. Chem. Soc. Vol-124, NO. 7 (2002) 1430-7.

[8]. D. Stassi, S. Donadio, M. J. Staver, et al., Identification of a Saccharopolysporaerythraeagene required for the final hydroxylation step in erythromycin biosynthesis, J. Bacteriol.175 (1), (1993) 182-9.

[9]. Shafiee, A., Hutchinson, C. R. Macrolide antibiotic biosynthesis: isolation and properties of two forms of 6-deoxyerythronolide B hydroxylase from Saccharopolyspora erythraea (Streptomyces erythreus). Biochemistry 26, (1987) 6204-6210. [PMID: 2446657].

[10]. L.Narhi, A. Fulco, Characterization of a catalytically self-sufficient 119,000-dalton cytochrome P-450 monooxygenase induced by barbiturates in Bacillus megaterium, J. Biol.Chem.261 (16), (1986) 7160-9.

[11]. H. Girvan, T. Waltham, R.Neeli, et al., Flavocytochrome P450 BM3 and the origin of CYP102 fusion species, Biochem. Soc. Trans. 34, (2006) 1173-7.

[12]. X. Chen, A. Christopher, J.P. Jones, et al., Crystal structure of the F87W/Y96F/V247 Lmutant of cytochrome P450cam with 1,3,5trichlorobenzene bound and further protein engineering for the oxidation of pentachlorobenzene and hexachlorobenzene. $J$. Biol. Chem. 277, (2002) 37519-52.

[13]. D.G. Kellner, S.A. Maves, S.G. Sligar, Engineering cytochrome P450s for bioremediation, Curr. Opin. Biotechnol.8 (3), (1997) 274-8.

[14]. R. J. Lewis, S.Belkina, T. A.Krulwich, Alkalophiles have much higher cytochrome contents than conventional bacteria and their own non-alkalophilic mutant derivatives. Biochem. Biophys. Res. Commun.95, (1980) 857-63.

[15]. [15] M.W. Davidson, K. A. Gray, D. B.Knaff, et al., Purification and characterization of two soluble cytochromes from the alkalophileBacillus firmus RAB. Biochim. Biophys. Acta.933, (1988) 470-7.

[16]. I. Yumoto, Y. Fukumori, T. Yamanaka, Purification and characterization of two membrane-bound c-type cytochromes from a facultative alkalophilicBacillus. J. Biochem.110, (1991) 267-73.

[17]. I. Yumoto, N. Kenji, I. Koji, Comparative Study on Cytochrome Content of AlkaliphilicBacillus Strains, J. Ferment. \&Bioenq. Vol.83, No.5, (1997) 466-9.

[18]. R. L. Wright, K. Harris, B. Solow, et al., Cloning of a potential cytochrome P450 from the archaeonSulfolobussolfataricus, FEBS. Lett. 384 (3), (1996) 235-9.

[19]. J.Rittle, M.T. Green, Cytochrome P450 Compound I: Capture, Characterization, and C-H Bond Activation Kinetics,Science. 330,6006, (2010) 933-7.

[20]. R.Aono, K.Horikoshi, Chemical composition of cell walls of alkalophilic strains of Bacillus. J. General Microbiology. 129, (1983) $1083-87$. 
[21]. B. E. Jones, W. D. Grant, A. W. Duckworth, et al., Microbial diversity of soda lakes. Extremophiles.3, (1998)191-200.

[22]. P.Chomczynski, K. Mackey, R.Drews, et al.,DNAzol: a reagent for the rapid isolation of genomic DNA, Biotechniques. 22, (1997)550-3.

[23]. F. Sanger, S. Nicklen, A.R. Coulson, DNA sequencing with chain-terminating inhibitors 1977, Biotechnology.24, (1992)104-8.

[24]. Saitou N, NeiM. The neighbor - joiningmethod: a newmethod for reconstructing phylogenetic trees.Mol.Biol.Evol. 4, (1987)406-25.

[25]. Tamura K, Dudley J, Nei M, et al., MEGA4: molecular evolutionary genetics analysis (MEGA) software version 4.0. Mol. Biol. Evol.24, (2007)1596-9.

[26]. Tamura K, Nei M, S. Kumar, Prospects for inferring very large phylogenies by using the neighbor-joining method. Proc. Natl. Acad. Sci. USA.101, (2004) 11030-5.

[27]. O.H. Lowry, N.J.Rosebrough, A.L. Farr, et al., Protein measurement with the Folin phenol reagent. J. Biol. Chem.193, (1951)26575.

[28]. T. Omura, R. Sato, The carbon monoxide-binding pigment of liver microsomes. I. Evidence for its hemoprotein nature. J. Biol. Chem. 239 (1964) 2370-8

[29]. R.M.C.Dawson, D.D.Elliott, W.H Elliott, et al., Oxford University Press, Methods in Enzymology, Vol. I, (1955) pp. 76.

[30]. D. Keillin, E.F. Hartree, Proc.Roy. Soc. (London) B124, (1938) 397

[31]. U. K.Laemmli, Cleavage of structural proteins during assembly of the head of bacteriophage T4, Nature. 277, (1970) 680-5.

[32]. J. Schenkman, H Remmer, R. W. Estabrook,Spectral Studies of drug interaction with hepatic microsomal cytochrome P450,MolPharmacol . 3 (2), (1967) 113-123.

[33]. T. Ommura, in Microsomes and Drug Oxidations (J. R.Gillette, A. H.Conney, G. J. Cosmides, R. W.Estabrook, J . R. Faits, G. J.Mannering, (Eds.),Academic Press, New York,1969, pp. 160-161.

[34]. I. G. Denisov, Shao-Ching Hung, K. E. Weiss,et all, Characterization of the oxygenated intermediate of the thermophilic cytochrome P450 CYP119, J. Inorganic Biochem. 87 (2001) 215-226.

[35]. A.V. Puchkaev, P.R. Ortiz de Montellano, The Sulfolobussolfataricus electron donor partners of thermophilic CYP119: an unusualnon-NAD(P)H-dependent cytochrome P450 system, Arch BiochemBiophys. issue 1, vol. 434 (2005)169-77.

[36]. A. Schallmey, G.denBesten, Ite G. P. Teune, et all, Characterization of cytochrome P450 monooxygenase CYP154H1 from the thermophilic soil bacterium Thermobifidafusca, Appl. Microbiol. Biotech.89, (2011) 1475-1485.

[37]. J.Y. Kang, S.Y. Kim, D. Kim, et al., Characterization of diverse natural variants of CYP102A1 found within a species of Bacillus megaterium, AMB Express.(2011) 1:1.

Table-1. Summary of purification of CYP-450 $0_{\text {cam }}$ from alkaliphilicKocuriasp DL.

\begin{tabular}{llllll}
\hline $\begin{array}{l}\text { Fractionation } \\
\text { Steps } \\
\text { involved }\end{array}$ & $\begin{array}{l}\text { Protein } \\
(\mathbf{m g})\end{array}$ & $\begin{array}{l}\text { CYP-450 cam content } \\
(\mathbf{n ~ m o l e / m g )}\end{array}$ & $\begin{array}{l}\text { Purification } \\
\text { fold }\end{array}$ & $\begin{array}{l}\text { Aminopyrine- } \boldsymbol{N} \text { - } \\
\text { demethylase }^{\#}\end{array}$ & $\begin{array}{l}\text { Acetanilide } \\
\boldsymbol{p} \text {-Hydroxylase* }\end{array}$ \\
\hline Sonication & 159.0 & 0.444 & 1 & 34.312 & 48.127 \\
$\mathbf{N H}_{4} \mathbf{S}_{\mathbf{2}} \mathbf{S O}_{4}$ ppt. & 83.3 & 0.69 & 1.55 & 40.64 & 55.31 \\
$\begin{array}{l}\text { DEAE cellulose column } \\
\text { Calcium phosphate gel }\end{array}$ & 46.25 & 0.892 & 2 & 47.4 & 68.32 \\
Sephadex G-75 column & 19.53 & 1.355 & 3.05 & 52.34 & 79.4 \\
\hline
\end{tabular}

\#nmol of formaldehyde formed $/ \mathrm{min} / \mathrm{mg}$ of protein, $* \mathrm{n}$ mol of $p$-hydroxyl acetanilide $/ \mathrm{min} / \mathrm{mg}$ of protein

Table-2. Kinetic properties of CYP-450 ${ }_{\text {cam }}$ monooxygenase

\begin{tabular}{|c|c|c|c|}
\hline Substrate & $\begin{array}{l}\mathbf{K}_{\mathrm{m}} \\
(\mu \text { mol.ml } \\
(\mu)\end{array}$ & $\begin{array}{l}V_{\max } \\
\left(n \text { mol. } \mathrm{mg}^{-1} \text { protein } \min ^{-1}\right)\end{array}$ & $\mathbf{K}_{\text {cat }}\left(\mathbf{S}^{-1}\right)$ \\
\hline Aminopyrine & 0.4 & 12.98 & \pm 9.19 \\
\hline Acetanilide & 0.25 & 13.2 & \pm 8.35 \\
\hline
\end{tabular}

Fig. 1

(A)

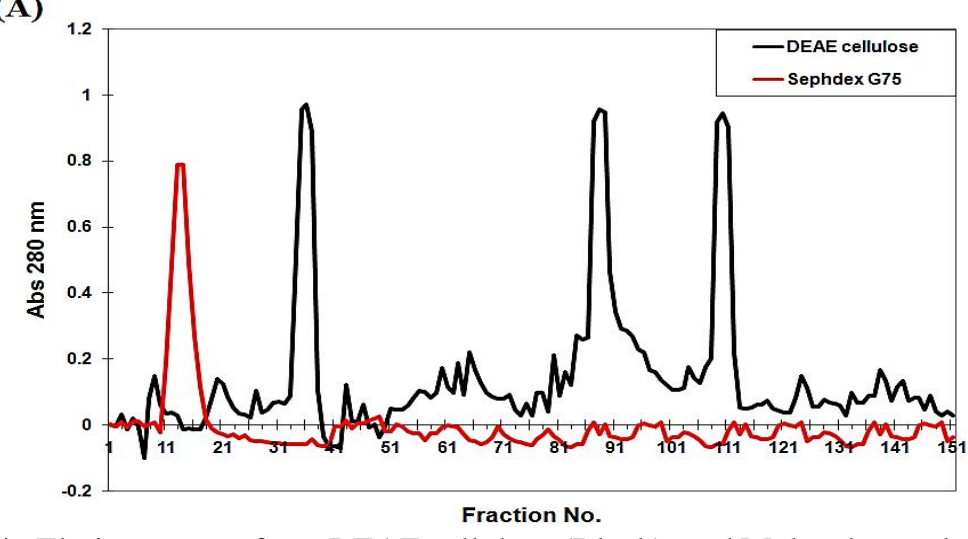

(B)

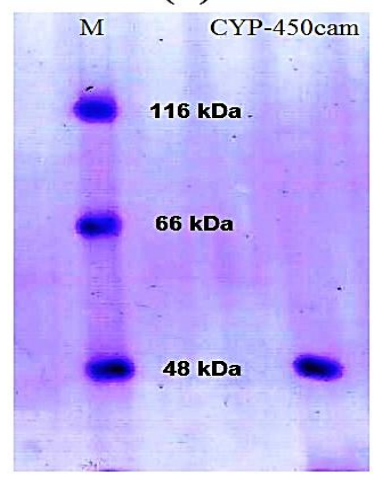

Fig. 1. A. Elution pattern from DEAE cellulose (Black), and Molecular exclusion Sephadex G-75 (Red) column chromatography.B. SDS-PAGE pattern of purified CYTP-450cam. Lane M: Protein Molecular Markers. Gel was stained with Gel was stained with $1 \%$ Coomassie brilliant blue R-250 staining. 
Fig. 2

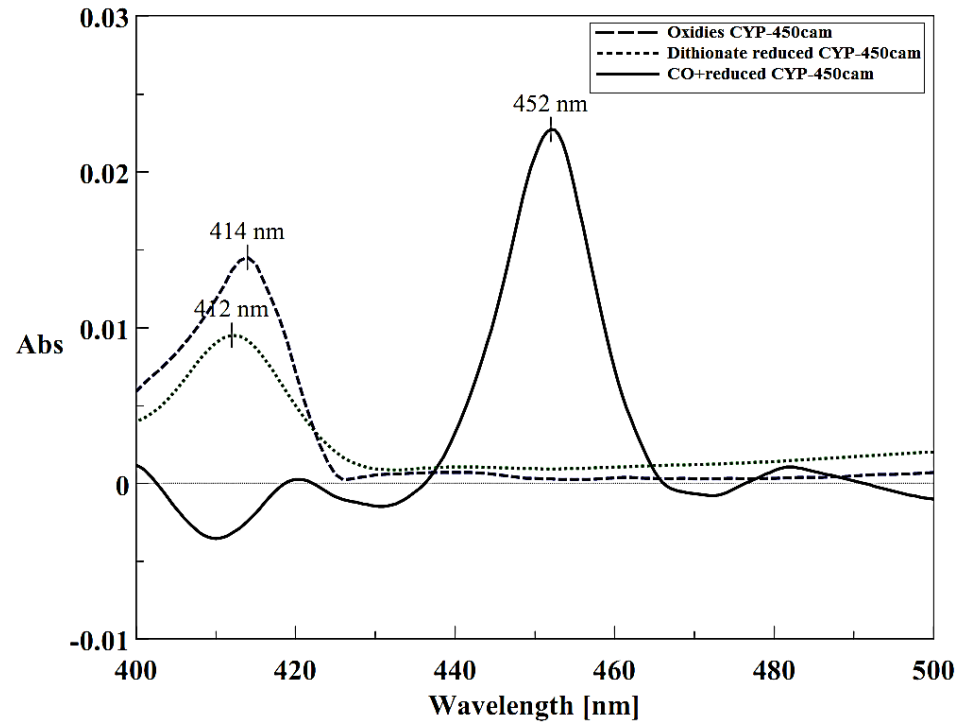

Fig. 2. Absolute absorbance spectra of purified CYP-450 cam from Kocuria sp. DL., CO + reduce Cytochrome P$450_{\text {cam }}$ (black) oxidized CYP450 $0_{\text {cam }}$ form at $414 \mathrm{~nm}$ (Blue dot .....), sodium dithionate reduce $412 \mathrm{~nm}$ green dash $(---)$.

Fig. 3
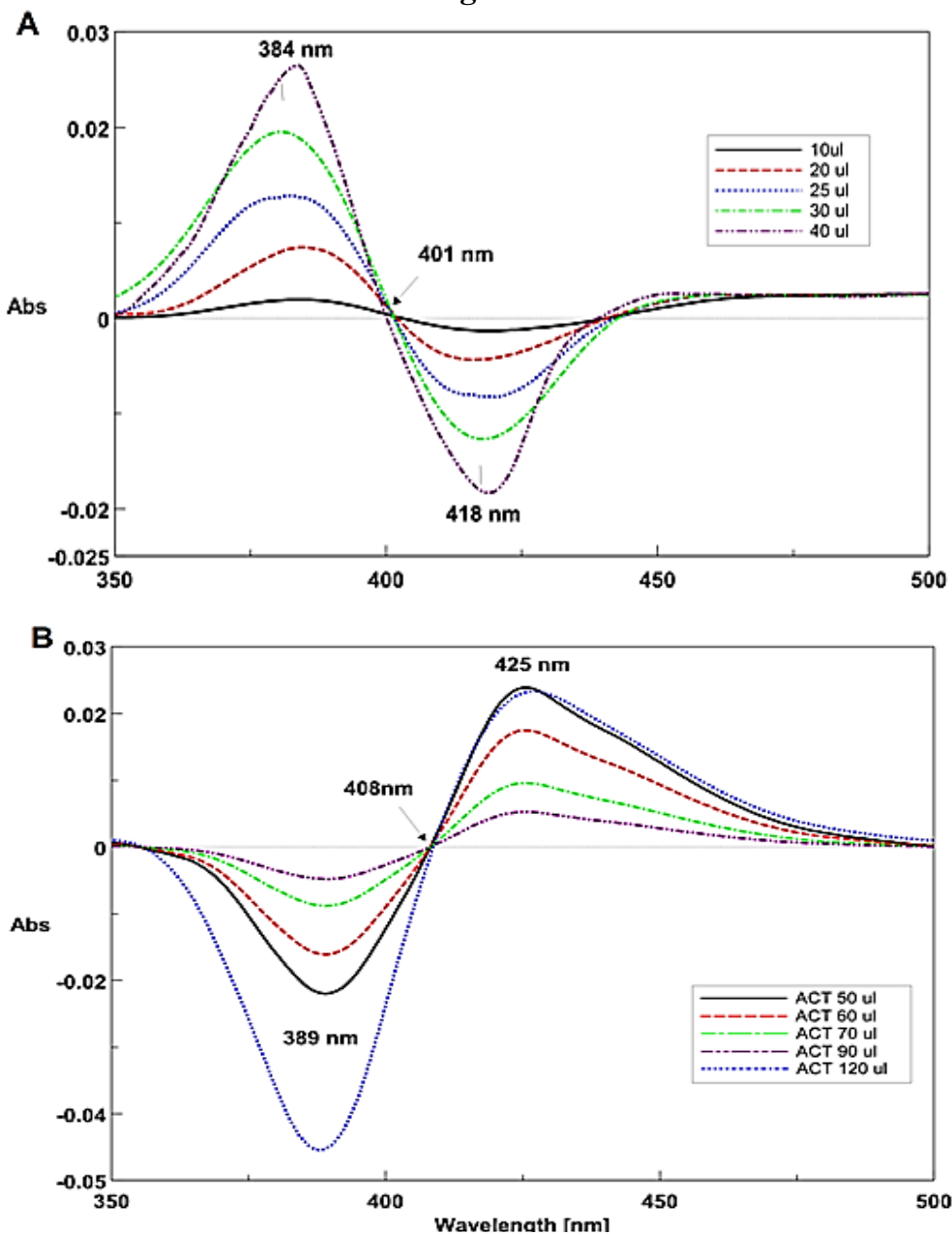

Fig. 3 A. Effectof aminopyrine on absorption spectrum of purified CYTP- $450_{\text {cam }}$ showing Type-I substrate binding Spectra from 10-40 $\mu \mathrm{l}$ with isosbestic point $401 \mathrm{~nm}$, B. Type II substrate binding Spectra of acetanilide $50-110 \mu \mathrm{l}$ with isosbestic point at $408 \mathrm{~nm}$. 
Fig. 4
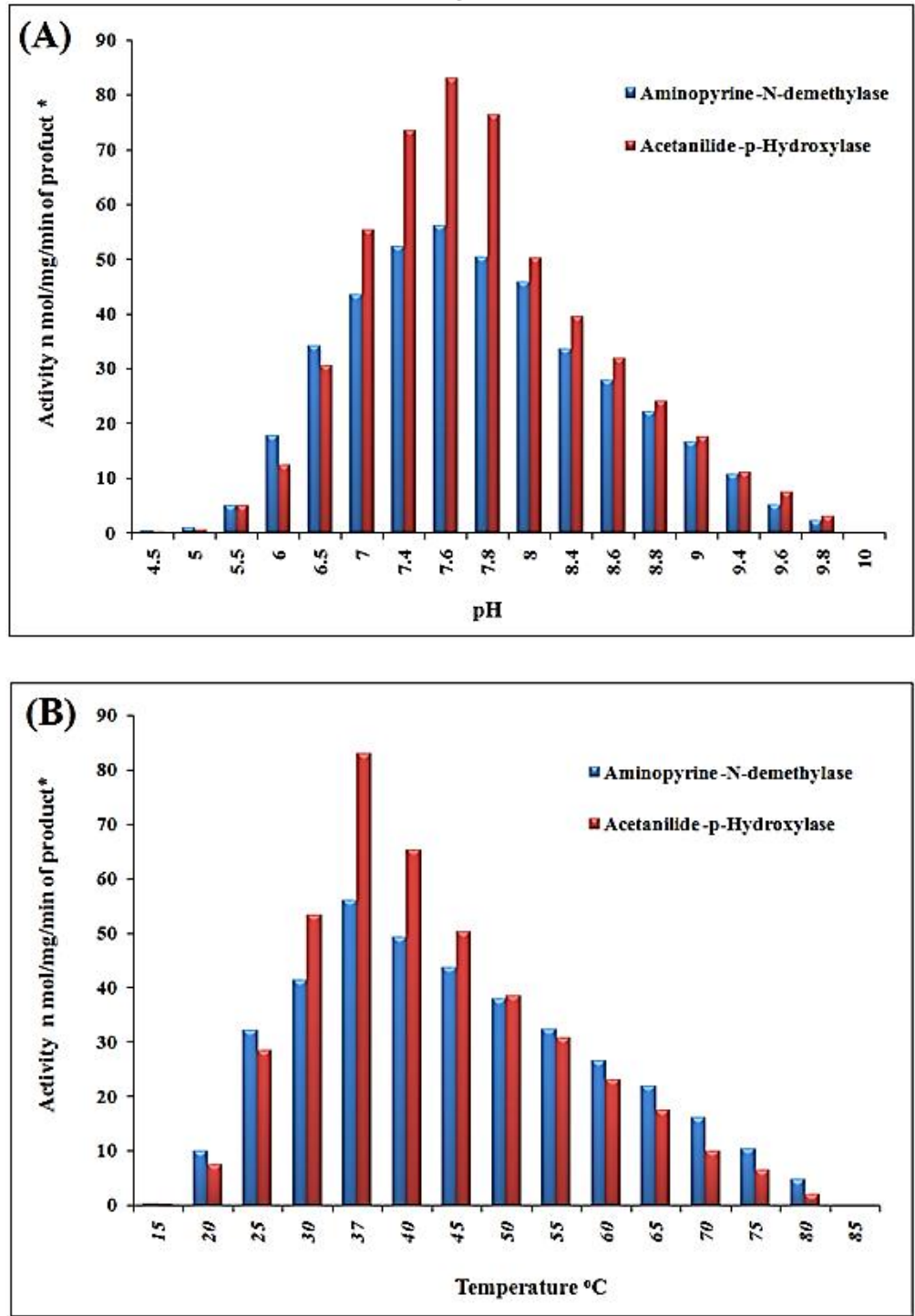

Fig. 4 A. Effect of $\mathrm{pH}$ and B. Temperature on aminopyrine- $N$-demethylase and acetanilide- $p$-hydroxylase activity of CYTP- $450_{\text {cam }}$, on the production of $\mathrm{n}$ mol of formaldehyde and $p$-hydroxyl acetanilide/ $\mathrm{min} / \mathrm{mg}$ of protein. 